\title{
ECONOMIC GROWTH AND JUDICIAL INDEPENDENCE: CROSS COUNTRY EVIDENCE USING A NEW SET OF INDICATORS
}

\author{
LARS P. FELD \\ STEFAN VOIGT \\ CESIFo Working PAPER No. 906 \\ CAtegory 2: Public ChOICE \\ APRIL 2003
An electronic version of the paper may be downloaded
- from the SSRN website: www.SSRN.com
- from the CESifo website: www.CESifo.de




\title{
ECONOMIC GROWTH AND JUDICIAL INDEPENDENCE: CRoss COUNTRY EVIDENCE USING A NEW SET OF INDICATORS
}

\begin{abstract}
Rational politicians are interested in judicial independence (JI) in order to make their promises credible. But if politicians' preferences deviate from the dicta of the judiciary, they also have incentives to renege on judicial independence. These two conflicting aspects are measured by two indicators: (i) de iure JI focusing on its legal foundations and (ii) a de facto JI focusing on countries' actually experience. Whether JI affects economic growth is tested for a cross section of 57 countries. While de iure JI does not have an impact on real GDP growth per capita growth, de facto JI positively influences it.
\end{abstract}

JEL Code: H11, K40, O40, P51.

Keywords: economic growth, rule of law, judicial independence.

Lars P. Feld

Philipps-University of Marburg

Public Finance Group

Am Plan 2

35037 Marburg (Lahn)

Germany

feld@wiwi.uni-marburg.de
Stefan Voigt

University GH of Kassel

FB 07

Nora-Platiel-Str. 4

34109 Kassel

Germany 


\section{$1 \quad$ Introduction}

Thriving market economies depend on strong states that secure private property rights and their voluntary transfer. Yet, the strength of the state can be its greatest weakness: if it is strong enough to secure private property rights, it could also be strong enough to attenuate them or even to expropriate its citizens (Weingast, 1993). A simple promise to honor private property rights in the future will not be credible: the citizens know that, after they have invested, the state has an incentive not to keep its promises and to hold citizens up. In such a setting, an independent judiciary could make all actors better off: if it is able to make the representatives of the state stick to their promises, additional (physical and human capital) investment could lead to higher income and growth, but also to higher tax receipts of the state.

It would thus seem that rational politicians should have introduced judicial independence for long. But simply promising an independent judiciary might not be sufficient to induce additional investment: as long as potential investors do not believe that the judiciary will really be impartial, they might not change their investment behavior. It thus seems to make sense to distinguish two kinds of judicial independence (JI), namely de iure and de facto JI. Whereas de iure $\mathrm{JI}$ can be derived from looking at the letter of the law, de facto $\mathrm{JI}$ is the independence factually enjoyed by judges and justices which will be the result of their effective term lengths, of the degree to which their judgments have an impact on government behavior etc.

In this paper, it is analyzed whether judicial independence is also conducive to economic growth. Two indicators of judicial independence are introduced: (i) a de iure indicator focusing on the legal foundations of judicial independence and (ii) a de facto indicator focusing on the factually ascertainable degree of judicial independence. For a sample of 66 countries an econometric model is estimated according to which real GDP growth per capita between 1980 and 1998 is explained by judicial independence and standard controls. While de iure judicial independence does not have any impact on economic growth, de facto judicial independence positively influences GDP growth. The model is extended by checking the robustness of the results to proxies for economic freedom, legal origin of a country and political stability.

The remainder of the paper is organized as follows: Section 2 elaborates possible consequences of JI on economic growth in a little more detail. In Section 3, the indicator is set into context with related literature. Section 4 presents the two indicators. In Section 5, the econometric model is introduced, Section 6 contains the discussion of the econometric analysis, and Section 7 concludes. 


\section{The Crucial Importance of Judicial Independence for Economic Growth and De- velopment}

JI implies that judges can expect their decisions to be implemented regardless of whether they are in the (short-term) interest of other government branches upon whom implementation depends. It would further imply that judges - apart from their decisions not being implemented - do not have to anticipate negative consequences as the result of their decisions, such as (a) being expelled, (b) being paid less, or (c) being made less influential.

Three archetypical interaction situations in which JI is important can be distinguished:

(1) In cases of conflict between citizens: If contracting parties voluntarily entered into a contract and one of the parties believes that the other side hasn't lived up to the contract, impartial dispute resolution is important. As long as both sides expect the judiciary to be impartial, they can save on transaction costs while negotiating the contract. On average, lower transaction costs will lead to more welfare-enhancing transactions taking place.

(2) In cases of conflict between government and the citizens, the citizens are in need of an organization that can adjudicate who is right, i.e. who has acted according to the law. The judiciary will not only have to ascertain the constitutionality of newly passed legislation but also to check whether the representatives of the state have followed the procedural devices that are to safeguard the rule of law. If the judiciary is not independent from executive and legislature, citizens will not trust in the relevance of the rule of law.

(3) In cases of conflict between various government branches: In the absence of an impartial arbiter, conflicts between government branches are most likely to develop into power games. An independent judiciary can keep them within the rules laid out in the constitution.

Among the many functions of government, the reduction of uncertainty is of paramount importance. But the law will only reduce uncertainty if the citizens can expect the letter of the law to be followed by government representatives. An independent judiciary could thus also be interpreted as a device to turn promises - e.g. to respect property rights and abstain from expropriation - into credible commitments. If it functions like this, citizens will develop a longer time horizon which will lead to more investment in physical capital but also to a higher degree of specialization, i.e., to a different structure of human capital. All this means that JI is expected to be conducive to economic growth. 


\section{Putting Judicial Independence Into Context}

We are not aware of any indicators measuring both de iure and de facto JI. Nevertheless, there is, of course, a literature dealing with JI and its effects. Judicial independence has been modelled as the amount of discretion that judges have at their disposal vis-à-vis representatives of other government branches. This has typically been done using spatial voting models (Moser, 2000 is an overview with applications to a number of independent agencies). ${ }^{1}$ With regard to any decision, the ideal points of all relevant actors are somehow distributed in space. The amount of discretion that the judiciary has at its disposal depends on the exact location of the ideal points of the other actors. If it anticipates their location correctly, it can make a decision that maximizes its own utility subject to the relevant constraints that is (i) the danger of being overridden by fresh legislation that would be passed through the legislature or (ii) by having its dicta ignored by the executive. These models particularly focus on the power game played between representatives of the various government branches. Applying them empirically is, however, often close to impossible as the relevant dimensions of many issues are not evident and the ideal points of many actors are difficult to identify. We therefore chose another approach to derive cross country comparisons regarding de iure and de facto JI.

The literature analyzing the effects of central bank independence (CBI) on inflation is more closely related to the approach towards JI presented here. Various approaches towards measuring CBI have been proposed (Cukierman, 1992, Cukierman/Webb/Neyapti, 1992, Debelle/ Fisher, 1995, Grilli/Masciandaro/Tabellini, 1991 are examples). It turns out that de iure CBI is a good predictor for monetary stability only in OECD countries but that the turnover rate of central bank governors (a de facto proxy) is a much better predictor for less developed countries (Berger et al., 2001 and Hayo/Hefeker, 2002 are two recent surveys). Keefer and Stasavage (2001) have added to this literature by pointing out that a higher number of political veto players increases the chances that formal CBI will be correlated with low inflation levels.

It can be argued that there are a number of structural similarities between the role and effects of central banks and the judiciary. The most important similarity is probably that both the judiciary and a central bank can help government to mitigate a credibility problem. That go v-

1. There are models on judicial discretion in statutory interpretation (e.g. Ferejohn and Weingast, 1992) and on the reactions of the legislature (e.g. Gely and Spiller, 1990). Others have analyzed the relationship between Congress and bureaucracy extensively (McCubbins and Schwartz, 1984, McCubbins, Noll, Weingast, 1987, 1989; Moe, 1990; Macey, 1992; Zeppos, 1993). There is plenty of institutional detail in these models. This, however, is also one of their weaknesses as they are almost exclusively focused on the U.S. 
ernment runs into a time inconsistency problem if it does not delegate monetary policy is widely acknowledged (Kydland/Prescott, 1977, Barro/Gordon, 1983). As shown in the last section, government also runs into a credibility problem concerning the safety of property rights if there is no neutral and independent arbiter who has the power to adjudicate whether go vernment action has remained within the letter of the law (i.e., the 'promises' of the government). Some of the variables used here were inspired by the indicators used to measure CBI.

\section{$4 \quad$ Introducing Two New Indicators}

\subsection{Introductory Remarks}

In this paper, we introduce two indicators that are as objective as possible. They are based on verifiable facts and not on subjective evaluations. ${ }^{2}$ Anybody interested in recalculating them should, in principle, arrive at identival values. The components making up our indicator of judicial independence reflect the major aspects one has conventionally in mind when talking about these concepts. We are interested in a measure of the independence of an entire go vernment branch. In many states, this branch is made up of thousands of decision-makers. Often, there is an elaborate division of labor between specialized courts. In federal states, there usually is a state judiciary, which is separate from the federal one. In short, complexity needs to be radically reduced. We therefore propose to focus on just one court for every country, namely its highest court. Regardless of whether it deals exclusively with constitutional issues (as, e.g., the German Constitutional Court) or whether it is the Supreme Court for all areas of law (as, e.g., the U.S. Supreme Court), it will deal with interpreting the Constitution. If the Constitution is viewed as the most basic rule set of a state, its interpretation will be of great importance. The court system is organized hierarchically, with the higher courts being able to overrule the sentences of the lower courts. It is therefore the independence of the highest court that is important for the degree of judicial independence observed in a polity. ${ }^{3}$

2. The full text of the questionnaire on which the two indicators are based is reprinted in the appendix. The appendix also includes the detailed coding of the two indicators of judicial independence. Note, however, that the coding was only added here and was not part of the questionnaire as sent to the experts.

3. It can, of course, be argued that private law courts are more relevant for the security of property rights and investment behavior than constitutional courts. For a follow-up study, it would thus be interesting to measure the independence of private law courts and compare it with the indicators presented here. 


\subsection{A de iure Indicator for Measuring Judicial Independence}

This measure is solely based on the legal foundations as found in legal documents. We draw on 23 characteristics grouped into twelve variables in order to assess JI. Each of the twelve variables can take on values between 0 and 1 where greater values indicate a higher degree of JI. A country with a maximum degree of JI could thus get a sum of 12 . Unfortunately, for some of the countries included in this sample, we were not able to get data for all 12 variables. We therefore decided to divide the sum of the coded variables by the number of variables for which data was available. The indicator can thus take on any value between 0 and 1.4 Here is a list of the 12 variables and the reasoning used for coding them:

(1 and 2) The independence of judges is dependent upon the stability of the set of institutional arrangements within which they operate. Formally, the stability of the powers and procedures of the court depend on how difficult it is to change them. If they are specified in the constitution itself, we expect a greater degree of independence than in cases where these arrangements are fixed by ordinary law. This does only hold, however, if a majority is needed to change the constitution, which is more inclusive than that which is needed to pass ordinary legislation. We therefore asked (1) whether the highest court is anchored in the constitution and (2) how difficult it is to amend the constitution.

(3) The appointment procedure of the judges may have a notable effect on the independence of the court. As it is inter alia supposed to protect citizens from illegitimate use of powers by the authorities as well as to settle disputes between the branches of government, it ought to be as independent as possible from the other branches. We hypothesize that the most independent procedure for judicial appointment is by professionals (other judges or jurists). The least independent method is appointment by one powerful politician (the prime minister or the minister of justice, e.g.).

4. This means that equal weight is attached to all variables. It can, of course, be argued that they should be weighted according to their importance. This presupposes, however, that there is a theory according to which weights could be distributed. Such a theory is not available at present. One could also think of attaching weights ex post, for example by using factor analysis, such that the explanatory fit is maximized. Indeed any weighting is more or less arbitrary without the existence of a proper theory for construction of the indexes. This also holds with respect to factors extracted from the set of single variables. In the latter case, only statistical criteria are relevant in the construction of the index and it is up to the analyst to interpret the factors obtained. We leave a further discussion of different weights to future analysis and concentrate on the simplest method of computing the indexes by taking an (unweighted) average of the variables. 
(4/6) Judicial tenure will be crucial for the independence of the judiciary. We assume that judges are most independent if they are appointed for life (or up to a mandatory retirement age) and cannot be removed from office, save by legal procedure.

(5) Judges are less independent if terms are renewable because they have an incentive to please those who can reappoint them.

(7) Further, if the members of one of the other government branches enjoy discretion in determining the salaries of the judges, this raises incentives to take the preferences of these members explicitly into account. In contrast, general rules that their salaries cannot be reduced increase, in turn, the independence of the judiciary.

(8) Additionally, judges need to be paid adequately in comparison with other jobs that qualified lawyers can exercise such as practicing as a private lawyer or teaching as a university professor.

(9) Another component of judicial independence is the accessibility of the court and its ability to initiate proceedings. A court which is accessible only by a certain number of members of parliament or other officials will be less effective in constraining government vis-à-vis its citizens than a court, which is accessible by every citizen who claims that her rights are violated. 5

(10) If the allocation of cases to the various members of the court is at the discretion of the chief justice, his influence will be substantially greater than that of the other members of the court. It follows that in such an institutional environment, it could be worth trying to 'buy' just the chief justice. We expect independence to be larger if there is a general rule according to which cases are allocated the responsibility of single members of the court.

(11) The competencies assigned to the constitutional court do not bear directly on its independence. Yet, highest courts must have certain competencies in order to be able to check the behavior of the other government branches. If the constitution is interpreted as the most basic formal layer of rules that is to restrain (and to enable) government, then constitutional review, i.e. the competence of the court to check whether legislation is in conformity with the constitution is crucial.

5. One referee pointed out that this might easily lead to congestion problems which might, in turn, paralyze the court and undermine its position. Resources for judicial decision-making are indeed scarce but that does not seem a good reason not to grant effective legal protection to individual citizens. Facing scarce resources, courts will devise their own procedures of access. The examples of the U.S. and Germany seem to indicate that this does not need to undermine the position of the court. 
(12) If courts have to publish their decisions, they can be scrutinized by others and the reasoning can become subject to public debate. This can be interpreted as making it more difficult for representatives of the other government branches to have irrelevant considerations influence their decisions. The transparency will be even higher if the courts publish dissenting opinions.

\subsection{A de facto Measure for Judicial Independence}

We now turn to possible ways of measuring JI not as it is written down in legal documents but as it is factually implemented. As with regard to the de iure indicator, no one single proxy adequately reflects all relevant aspects of JI. To assess de facto JI, eight variables have been used. Again, each of the eight variables can take on values between 0 and 1 where greater values indicate a higher degree of JI.

The de iure indicator is based on various legal documents. Even if they are changed frequently, exact values can be calculated for every single point in time, depending on the formal validity of the respective documents. This does not hold for de facto JI. The factual term length of Highest Court judges cannot be calculated right after a new constitution has been passed but will be the result of years of living with the legal documents. We therefore base the de facto indicator on quite a long period, namely that between 1960 and today. This means, of course, that the indicator will be very sticky in comparison to the de iure indicator. Some respondents simply did not answer to the second part of the questionnaire because they believed it did not apply to their countries. The countries of Central and Eastern European are a case in point here: all of them passed new constitutions after 1990. According to the time span proposed by our indicator, the treatment of the judiciary by socialist regimes still weighs heavily on today's de facto values. We chose this approach because we think the past matters for how $\mathrm{JI}$ is evaluated by citizens and other potential investors. A government - or more broadly: a regime - will not be able to build up a reputation as law-abiding or JI-respecting overnight. Here is a list of the eight variables and the reasoning used for coding them:

(1-3) A crucial aspect of the de facto JI will be the effective average term length of the members of the highest court. ${ }^{6}$ For coding, we simply multiplied the effective average term length in years with 0.05 . In other words: a country gets the highest possible rating 
if the average term length is twenty years (or more). If the actual term length and the one to be expected on the basis of the legal foundations deviate, the country is coded 0 in the following variable. Removing a judge before the end of term is a serious breach of JI. Whenever that has occurred at least once, the country is coded 0 for that variable.

(4) The influence of a judge depends on the number of other judges who are members of the same court. By increasing the number of judges, the weight of those judges who do not decide along the lines of the preferences of the median members of the other branches can supposedly be diminished. This is exactly what President Roosevelt had in mind with his plan to 'pack' the Supreme Court. It was thus asked how many times the number of judges had been changed since 1960 .

(5-6) The importance of an adequate income was already discussed with regard to the de iure indicator. With regard to the de facto situation, we were interested to learn whether the incomes of judges have at least remained constant in real terms. But the efficacy of courts does not only depend on the income level of judges but also on the number of clerks employed, the size of the library, the availability of modern computer equipment etc. We have tried to take this aspect into account by asking for the development of the court's budget as an organization.

(7) Any change in the basis of the legal foundation of the highest court will increase uncertainty among its potential users, i.e. will be counter to one of the most fundamental functions of the law. Frequent changes of the respective legal rules are here interpreted as an indicator for low de facto independence.

(8) The de facto degree of judicial independence is low if decisions of the highest court, in order to be implemented, depend on some action of one (or both) of the other branches of government and this cooperation is not granted. The more frequently this has been the case, the less independent is JI supposed to be factually.

The de iure indicator has been calculated for 75 countries. Getting data for the de facto indicator is more difficult than for the de iure indicator. In order to ensure a minimum amount of accuracy, countries were only ranked if a minimum of three variables for de facto independence were available. This explains the lower number of countries ranked here (namely 66).

6. This variable is closely reminiscent of the turnover rate calculated for central bank governors and used as a proxy for their de facto independence. Henisz (2000) has calculated this variable for the tenure of supreme court judges for 45 countries for the period from 1960 to 1990. 
Information was enquired by country experts via a questionnaire that was e-mailed to them jointly with a short paper explaining purpose and hypotheses of the enterprise. For filling in the questionnaire, the country experts did not have to make personal evaluations of the situation in the country, but were asked to simply give information on the legal structure of the judiciary. Among the country experts were Supreme Court judges, law professors, lawyers but also activists from organizations such as Transparency International. Mails were sent to far more than 75 experts but many recipients never answered or promised to fill in the questionnaire later. The choice of countries could be called 'biased random' due to a number of factors: contacts to legal experts are not equally spread around the world, use of e-mail is also not equally distributed around the world. But cultural factors might also play in. The Middle and Far East as well as Africa are clearly underrepresented in our study.

\subsection{A Comparison of Indicators}

The ranking of countries according to the de iure index (Appendix 2) at first sight contains more than one surprise: among the nine top-scoring countries, there is not one single OECDmember. Long established democracies with affluent economies such as the U.S. or Switzerland fare rather badly: the U.S. is ranked 30th, Switzerland with its 67th rank even belongs to the lowest-ranked quintile. However, this ranking solely reflects JI as it is written down in various legal documents. Politicians all over the world have incentives to promise to their citizens that the judiciary will be independent. Most of the top-ranked countries have, e.g., close ties with the U.S. and U.S.-American legal thinking, which emphasizes the importance of judicial independence. ${ }^{7}$ Large parts of Georgia's Constitution were drafted by law professors from Chicago Law School. It is not astonishing that they put heavy emphasis on the formal independence of the judiciary. What will be more interesting therefore is to inquire whether the de facto indicator reflects a similar ranking or whether the two indicators diverge.

There is indeed a notable divergence between both indicators of judicial independence. Not a single country in the 'Top Ten' of the de iure JI index is in the 'Top Ten' of the de facto JI index. Moreover, like in the case of the de iure index, the ranking of the de facto index is rather unexpected: The good results of Armenia and Kuwait in the ranking (Appendix 3) can probably be made plausible by the low number of variables used (namely 3), but this does not

7. These countries outrank the U.S. because some of the competencies that the U.S. Supreme Court factually holds - such as constitutional review - only emerged over time but are not fixed in the constitution. Most of the more recent constitutions incorporate this competence on the constitutional level. 
explain the good ranking of, say, Turkey (six variables) or Taiwan (eight). On the other hand, the good ranking of Switzerland as well as the fact that there is no EU member state among the lowest quintile conforms more strongly to common prejudices. Among the lowest quintile are only one OECD-member (the Czech Republic which has been a member since 1995), but some of the East European and African states that one would intuitively expect to fare badly.

It cannot be completely excluded that some questionnaire respondents pursue their own agenda and have an incentive to make reality fit to it: a loyal citizen could try to make his country look better than it really is whereas a political activist striving for improvement might try to make her country look worse than it really is. Respondents may have a tendency to give the 'socially desired' answers. It should also be noted that in principle, a judiciary that scrupulously follows the wishes of - say - the executive could score very well in the de facto score: a dictator could nominate one's family and friends as judges; as long as they conformed to his wishes, he would not have any incentives to kick them out of office, to reduce their salary or the budget of the court etc. This can indeed not be entirely excluded. The question would be as to what aspects we could check for in order to insure that this is not the case. The number of laws struck down by the highest court as unconstitutional (may be as a proportion of all laws passed) is not a good proxy for a number of reasons: (i) often, the highest court does not have the competency to initiate constitutional review; it thus depends on others initiating this process; (ii) the legislature will not naïvely maximize the utility of its median member but will try to anticipate the position of the court and will subsequently adjust its own position in order not to be called back by the court. ${ }^{8}$ In that sense, a law that is struck down by the court represents an expression of faulty expectations concerning jurisdiction by the majority of the legislature.

We now turn to discussing the correlation with various indicators that serve similar purposes (Table 1). The rule of law-data are provided by the publishers of the International Country Risk Guide (ICRG), an organization which sells information to private firms interested in business relations. ${ }^{9}$ We use the data as they are provided by the authors of the Economic

8. Voigt (1999) explores the relevant strategic interactions between the members of the three government branches in more detail.

9. Unfortunately, they have already been corrected. Ratings for some countries rated here were not provided for by ICRG: Estonia and Lithuania were rated on the basis of Poland and Russia, Slovenia on that of the Czech Republic and Slovakia. Another country for which we provide original data was scored according to the ratings of apparently similar countries, namely Mauritius on that of Botswana. 
Freedom Index (Gwartney, Lawson, and Samida, 2000). There, the fifth out of seven groups of variables is entitled 'Legal Structure and Property Rights'. The specific variable is described as 'Rule of Law: Legal Institutions, Including Access to a Nondiscriminatory Judiciary That Are Supportive of the Principles of Rule of Law'. It is still astonishing that the correlation with our de iure indicator does not even have a positive sign; this is the case with the correlation between our de facto indicator and the rule of law-data but the correlation is far from perfect even then. Something similar happens with the data provided by the Economist Intelligence Unit (EIU) that are supposed to proxy for the transparency and accountability of the legal systems of 60 countries. Again, the correlation with the de iure index does not have a positive sign, while the one with our de facto indicator does.

Table 1: Correlation Matrix of the Indicators of Judicial Independence with Other Indicators

\begin{tabular}{lccccccc}
\hline & De iure & De facto & $\begin{array}{c}\text { Rule of } \\
\text { Law }\end{array}$ & $\begin{array}{c}\text { Transpar- } \\
\text { ency }\end{array}$ & $\begin{array}{c}\text { Civil } \\
\text { Liberty }\end{array}$ & $\begin{array}{c}\text { Property } \\
\text { Rights }\end{array}$ & $\begin{array}{c}\text { "Smithey } \\
\text { De iure }\end{array}$ \\
De facto & 1 & & & & & & \\
Rule of Law & 0.179 & 1 & & & & & \\
Transparency & -0.116 & 0.317 & 1 & & & & \\
Civil liberty & -0.063 & 0.573 & 0.594 & 1 & & & \\
Property Rights & -0.109 & -0.335 & -0.489 & -0.773 & 1 & & 1 \\
'Smithey' & -0.204 & -0.409 & -0.615 & -0.828 & 0.705 & 1 & \\
\hline
\end{tabular}

Notes: 'Rule of law' as provided by the Economic Freedom Index (Gwartney, Lawson, and Samida, 2000); The index on transparency and accountability of the legal systems is taken from the Economist Intelligence Unit; Freedom House (2001) represents the civil liberties on a scale between 1 and 7 where 1 represents the best possible value. Note that a negative sign with the other indicators stands for a positive correlation. The Heritage Foundation in conjunction with the Wall Street Journal offer another index of economic freedom (Heritage Foundation and Wall Street Journal, 2002). The variable used here is the one on property rights. The rights are on a scale between 1 and 5 where 1 stands for the highest possible value (correlations should thus have a negative sign safe for the one with the Freedom House data) and 'Smithey' is the shorthand for the various degrees of 'judicial power and independence' chosen in the transition countries of Central and Eastern Europe as reported and calculated by Smithey and Ishiyama (2000).

'Smithey' is the shorthand for a paper by Smithey and Ishiyama (2000) who try to explain the various degrees of 'judicial power and independence' chosen in the transition countries of Central and Eastern Europe. They construct a 'judicial power score' that has some similarities with the one constructed here. It is very surprising that it is negatively correlated with our $d e$ iure score whereas it is positively correlated with our de facto score. Part of the problem might be the small sample overlap: data from both sets exist for only 14 countries.

Many correlation coefficients are very low which is irritating at first sight. It can be argued however that the various indicators measure different things. If the correlation between these 
indicators is relatively low, it simply means that the relationships are not as straightforward as sometimes assumed. ${ }^{10}$ But let us now turn to an econometric analysis of the impact of judicial independence on economic growth.

\section{$5 \quad$ Estimation Approach and Data Description}

The workhorse for the empirical analysis is an equation that de Haan and Sturm (2000) call 'a variant of the Extreme Bounds Analysis (EBA)' (p. 228) with the difference that we do not report the extreme bounds but different estimation results providing for the extreme bounds. According to this approach the following equation is estimated:

$$
\Delta Y_{i}=\alpha M_{i}+\beta J I_{i}+\gamma Z_{i}+\varepsilon_{i},
$$

where $\Delta Y_{i}$ is average real GDP growth per capita of country i between the years 1980 and $1998, M_{i}$ is a vector of standard explanatory variables of country $\mathrm{i}, J I_{i}$ are the de iure and de facto indicators of judicial independence in country $i, Z_{i}$ is a vector of additional explanatory variables in country $i$ that are introduced to check the robustness of the baseline model, and $\varepsilon_{i}$ is an error term.

Average real GDP growth per capita is obtained from the new Penn World Tables Version 6.0 (Heston, Summers and Aten, 2001) which has been authorized for use in the end of December 2001 and revised in summer 2002. The data set poses particular problems with respect to Eastern European countries. Since the data of these countries in the nineties are not comparable to data in the eighties or do even not exist for the eighties because these are newly created states, real GDP growth per capita had to be averaged for these countries depending on the first date GDP data are available instead of averaging it for the time period 1980 to $1998 .{ }^{11}$ The use of the PWT 6.0 data set reduces the sample from 75 countries covered by the de iure

10. It could be argued that JI is a crucial precondition for safe property rights. Yet, it is surely not a sufficient condition. Enquiring more closely into these relationships could be a topic for an additional paper.

11. Real GDP growth per capita is averaged in the following way: Slovak Republic 1987 to 1998, Czech Republic and Slovenia 1990 to 1998, Bulgaria and Russia 1991 to 1998, Armenia and Estonia 1992 to 1998 , Lithuania 1993 to 1998, Azerbaijan and Kazakhstan 1994 to 1998, Croatia 1995 to 1998 and Georgia 1996 to 1998. Real GDP growth per capita thus reflects less and less the long run growth rate that is supposed to be measured according to the underlying growth theory. This is particularly problematic in the case of Georgia. The structural shift between West German and Unified German growth data is coped with in the following way: First, the average growth rate of GDP is computed for the period 1980 to 1990 for West Germany. Second, we compute the average growth rate of GDP for the period 1990 to 1998 for Unified Germany. Third, we take the mean of both rates. 
index and 66 countries covered by the de facto index to 66 and 57 countries respectively. Compared to Appendix 2 and 3, the countries Bahamas, Coratia, Kuwait, Montenegro and Vanuato had to be excluded from the sample.

The vector $M_{i}$ consists of three variables, which are robustly linked to economic growth according to previous studies (see de Haan and Sturm, 2000). These variables are the level of initial real GDP per capita (in our sample, 'initial' is 1980), private and public investment in percent of GDP averaged over the period 1980 to 1998, and the percentage of secondary school attained in the total population aged 15 and more in 1980. With the exception of the latter variable, which is from the Barro and Lee data set, these data are from the PWT 6.0.

The additional economic variables making up for the vector $Z_{i}$ are average government consumption in percent of GDP between 1980 and 1996, openness measured by the sum of exports and imports in percent of GDP, average population growth between 1980 and 1998, and the average inflation rate, all from the PWT 6.0 data set. The reason for an inclusion of these variables for testing robustness of the impact of judicial independence stems from a whole bunch of empirical growth studies. Again, de Haan and Sturm (2000) provide an excellent selective survey on these arguments. In addition to these standard additional variables, the data by La Porta et al. (1999) on the legal origin of countries are used to test robustness of the growth impact of JI to the legal and political environment. Moreover, the economic freedom indices as well as the political stability data by the World Bank (2001) and data on the age of a country's constitution are included for robustness checks in order to find out whether the impact of JI still holds if variables are included that may partly incorporate JI as a component or that appear to bear some relation to JI.

The empirical strategy is following along the lines underlying this model. First, the baseline regressions are performed adding the two JI indicators in turn. In a second step, the robustness of these results to outliers is checked because the shorter time period in which data are available for Eastern European and CIS countries may lead to specific problems. In a third step, the JI indices are differentiated into their single components. Fourth, the additional variables are included in the regression. We present only a selection of robustness checks in order to make the paper still readable. Several further variations of these regressions are not reported here which were also performed in order to check robustness. Finally, the robustness of the results to the construction of the de facto JI variable is tested. As mentioned above, those countries were included in the regression analysis that reported at least three components of 
the de facto index. Of course, it is an arbitrary decision how many questions one wants to have replied to. Since particularly the ranking of those countries with only three components appears to be surprising, e.g. Armenia, Kuwait, but also the Netherlands, regressions are eported for countries that answered four of the questions underlying the de facto JI index. The cross section analysis is performed by the simple OLS technique while inference is based on t-statistics computed on the basis of White heteroscedasticity consistent standard errors. ${ }^{12}$

\section{Estimation Results}

The estimation results of the baseline specification are presented in Table 2. It is obvious that the three basic economic variables explain average real economic growth per capita only modestly (Column (1)). The explanatory variables have the expected signs and some explanatory power however. Initial real GDP per capita has a negative impact on economic growth that is significant on the 5 percent significance level. Thus, a catch up-effect can be observed in the cross-country sample used here as well. The real investment share has the expected positive impact on economic growth and is significant on the 10 percent level. While the secondary school attainment rate has the expected positive impact it does not reach any conventional significance level. Given the inclusion of Eastern European and CIS countries to a cross-country sample and the potential problems in the reliability of their data from the eighties, the results for schooling should not be too disturbing.

The explanatory power is not improved if the de iure JI indicator is introduced in the model (Column (2)). The adjusted $\mathrm{R}^{2}$ increases from 12 to 15 percent only. Adding the de iure JI indicator to the baseline regression does not alter the estimation results. De iure JI has the expected positive impact on average real GDP growth per capita but it is not significantly different from zero. Introducing de facto JI instead of de iure JI (Column (3)) noticeably changes the estimation results however. It nearly doubles the explanatory power of the empirical model measured in the adjusted $\mathrm{R}^{2}$. Moreover, and as expected, de facto $\mathrm{JI}$ has a positive impact on real economic growth per capita and is significantly different from zero on the

12. We don't report the standard errors without White correction in order not to overburden the tables. They can be obtained from the authors upon request. It should be noted that with the exception of the clustering method for a correction of standard errors, the other corrections are unfriendly to institutional data. The White correction for heteroscedasticity consistent standard errors as well as the Newey-West correction for heteroscedasticity and autocorrelation consistent standard errors increase the standard errors and thus reduce significances. Clustering usually is unfriendly, but not necessarily so. For a comparison of the original standard errors with the three methods of correction see Feld and Matsusaka (2003). 
10 percent significance level. This result does not change if both indicators of JI are introduced in one equation (Column (4)). De facto JI has a significantly positive impact on economic growth while the positive impact of de iure JI is not significant.

Table 2: OLS-Regressions of GDP Growth per Capita from 1980 to 1998 on Judicial Independence and Controls, Baseline Specifications

\begin{tabular}{|c|c|c|c|c|c|}
\hline Variables & (1) & (2) & (3) & (4) & (5) \\
\hline $\begin{array}{l}\text { De iure Judicial Indepen- } \\
\text { dence }\end{array}$ & - & $\begin{array}{l}3.605 \\
(1.28)\end{array}$ & - & $\begin{array}{l}2.408 \\
(0.78)\end{array}$ & $\begin{array}{l}-0.505 \\
(0.26)\end{array}$ \\
\hline $\begin{array}{l}\text { De facto Judicial Independ- } \\
\text { ence }\end{array}$ & - & - & $\begin{array}{l}3.930(*) \\
(1.98)\end{array}$ & $\begin{array}{l}3.804(*) \\
(1.95)\end{array}$ & $\begin{array}{c}2.643(*) \\
(1.79)\end{array}$ \\
\hline $\begin{array}{l}\text { Real GDP per capita in } 1980 \\
\text { (in } \$ 1^{\prime} 000 \text { ) }\end{array}$ & $\begin{array}{l}-0.156^{*} \\
(2.61)\end{array}$ & $\begin{array}{c}-0.176^{*} \\
(2.53)\end{array}$ & $\begin{array}{l}-0.250 * * \\
(2.72)\end{array}$ & $\begin{array}{l}-0.254 * * \\
(2.70)\end{array}$ & $\begin{array}{c}-0.173^{* *} \\
(2.81)\end{array}$ \\
\hline $\begin{array}{l}\text { Secondary School Attain- } \\
\text { ment Rate in } 1980 \text { (in \%) }\end{array}$ & $\begin{array}{l}0.054 \\
(1.43)\end{array}$ & $\begin{array}{l}0.057 \\
(1.50)\end{array}$ & $\begin{array}{l}0.071 \\
(1.56)\end{array}$ & $\begin{array}{l}0.073 \\
(1.57)\end{array}$ & $\begin{array}{l}0.026 \\
(0.97)\end{array}$ \\
\hline $\begin{array}{l}\text { Real Gross Domestic In- } \\
\text { vestment (in \% of GDP), } \\
\text { Average in 1980-1998 }\end{array}$ & $\begin{array}{c}0.101(*) \\
(1.88)\end{array}$ & $\begin{array}{c}0.097(*) \\
(1.84)\end{array}$ & $\begin{array}{l}0.101 * \\
(2.07)\end{array}$ & $\begin{array}{c}0.097(*) \\
(1.90)\end{array}$ & $\begin{array}{c}0.155^{* *} \\
(4.85)\end{array}$ \\
\hline Dummy for Georgia & - & - & - & - & $\begin{array}{c}13.305^{* *} \\
(9.81)\end{array}$ \\
\hline Constant & -0.750 & -2.986 & -2.544 & -4.194 & -1.968 \\
\hline$\overline{\mathrm{R}}^{2}$ & 0.123 & 0.153 & 0.263 & 0.266 & 0.595 \\
\hline SER & 2.543 & 2.499 & 2.371 & 2.367 & 1.759 \\
\hline J. -B. & $226.253 * *$ & $151.088 * *$ & $118.143 * *$ & $81.629 * *$ & 3.313 \\
\hline Observations & 66 & 66 & 57 & 57 & 57 \\
\hline
\end{tabular}

The numbers in parentheses are the absolute values of the estimated t-statistics, based on the White heteroscedasticity-consistent standard errors. ' $* *$ ', '*' or ' $(*)$ ' show that the estimated parameter is significantly different from zero on the 1,5 , or 10 percent level, respectively. SER is the standard error of the regression, and J. -B. the value of the Jarque-Bera-test on normality of the residuals.

A basic problem in all equations presented in Table 2 is the fact that the hypothesis of a normal distribution of the residuals of each equation can be rejected on the 0.1 percent significance level. These test statistics indicate that outliers may be hiding in the data set that might drive the results. An analysis of the residuals reveals that Georgia is an outlier in that sense to any statistical criteria. Since only a short term growth rate is used for Georgia, it appears reasonable to introduce a dummy variable taking on the value of one for Georgia and zero otherwise. Including this dummy variable, the estimation results in Column (5) of Table 2 indicate that the hypothesis of normality of the residuals cannot be rejected any more according to the Jarque Bera test statistics. Real GDP growth per capita can be explained to nearly 60 percent. Aside the dummy variable for Georgia that is highly significant, the three basic economic variables keep their impacts qualitatively and have the expected signs. Both, domestic 
investment and initial GDP are significantly positive at the 1 percent significance level. The proxy for human capital does again not turn out to be statistically significant. Controlling for Georgia, de facto JI is significantly increasing real GDP growth per capita. The impact of de iure $\mathrm{JI}$ is neither significant nor is it robust to the outlier. The sign of the indicator of de iure JI reverses, although it is far from reaching significance. From this basic analysis, it can thus be concluded that de facto JI has a relatively robust and significant positive impact on GDP growth while the growth impact of de iure $\mathrm{JI}$ is zero.

\subsection{Analyzing Single Indicators}

From the previous results, a natural question emerges: What is driving the different results with respect to de iure and de facto JI? In order to find out the impact of different components of both JI indicators, we include the single indicators separately. Because the answers to the single questions underlying both indexes are not complete for each question, the missing values are set to the mean of each variable. This is a method that can be found quite often in survey studies. Although this might appear to be a questionable method, it does provide insights as to whether there are specific components of JI that exert particular impacts on economic growth. With respect to de iure JI, the respective results support those from the baseline specifications. Since one part of the different variables is positively and the other part is negatively correlated with GDP growth, it is no surprise that the index as an aggregate of those counterveiling influences does not have any impact. Moreover, nearly none of the single indicators exhibits a statistically significant impact on GDP growth. It does thus not appear to be particularly interesting to present these results in detail.

It could however be argued that only a selection of the components of de iure JI is necessary to establish JI. ${ }^{13}$ If parliament needs a supermajority to remove judges from the court, to change the rules for removing judges and if judges' salaries must be competitive, then judges have already arrived at a crucial 'minimum' set of factors establishing independence. In addition, it may play a role if the stability of the powers and procedures of the court are specified in the constitution itself. We therefore include only these three components of de iure JI, whether the procedures are specified in the constitution, whether there is a supermajority requirement and whether judges are adequately paid, in the model. The results are presented in Column (1) of Table 3. According to the $\chi^{2}$-statistics at the bottom of Table 3, the hypothesis 
that the three indicators are not jointly significantly affecting GDP growth can be rejected on the one percent level. Of these three variables, only the constitutional specification of the court's procedures has an individually significant effect on GDP growth and the expected positive sign. The supermajority requirement has the expected positive sign, but is not significant on any conventional level, while the adequate payment of judges has a negative sign without reaching significance. The impact of the control variables is not affected by this change in the specification. Nor are the diagnostic statistics.

This is different in the case of de facto JI as column (2) of Table 3 indicates. In contrast to de iure JI, it is less obvious that one of the components making up for the index could be interpreted as a necessary condition for de facto JI. Thus, all eight components of de facto JI are presented in Table 3. The $\chi^{2}$-statistics on joint significance of these eight components reveals that the hypothesis that these variables jointly have no impact on real GDP per capita growth can be rejected on the 1 percent significance level. This result is again merely reflecting the result for the composite index of de facto JI, but it clarifies as well that the single components of de facto JI exert a more homogeneous positive impact on GDP growth. Moreover, it appears to be statistically most important that judges of the highest courts keep their real income at least constant in real terms. The respective variable is by far the most important variable in statistical terms and is significant on the 1 percent level.

This result is critical because it might reflect a reverse causation effect: Judges' salaries are supposed to depend on income growth such that the impact runs from GDP growth to real income improvements instead of the opposite direction. This may severely affect the interpretation of the results as well if this is the most important variable for the index of de facto JI. We hence exclude the real income improvements as an explanatory variable. The results (in Column (3) of Table 4) are not tremendously affected by that change in the specification although all remaining eight indicators now have a positive impact on GDP growth. None of these influences is individually significant at any conventional level. The hypothesis that they are not jointly influencing GDP growth can however be rejected on the 10 percent significance level according to the $\chi^{2}$-statistics at the bottom of Table 3. Still, some worries remain as to the impact of the index of de facto JI in the baseline regressions.

13. We owe this suggestion to an anonymous referee. The results for the full set of components of de iure JI can be obtained from the authors upon request. 
Table 3: OLS-Regressions of GDP Growth per Capita from 1980 to 1998 on Single Components of Judicial Independence and Controls, 66 (57) Countries

\begin{tabular}{|c|c|c|c|c|}
\hline Variables & (1) & (2) & (3) & (4) \\
\hline Procedures Specified & $\begin{array}{l}8.987^{*} \\
(2.26)\end{array}$ & - & - & - \\
\hline Supermajority Requirement & $\begin{array}{r}0.534 \\
(0.51)\end{array}$ & - & - & - \\
\hline Adequate Payment of Judges & $\begin{array}{l}-0.174 \\
(0.20)\end{array}$ & - & - & - \\
\hline Effective Average Term Length of Judges & - & $\begin{array}{l}-0.135 \\
(0.12)\end{array}$ & $\begin{array}{r}0.061 \\
(0.05)\end{array}$ & - \\
\hline $\begin{array}{l}\text { Deviation from 'Normal' Average Term } \\
\text { Length }\end{array}$ & - & $\begin{array}{r}1.098 \\
(1.28)\end{array}$ & $\begin{array}{l}1.241 \\
(1.42)\end{array}$ & - \\
\hline Effective Removals before End of Term & - & $\begin{array}{l}0.536 \\
(0.86)\end{array}$ & $\begin{array}{l}0.516 \\
(0.82)\end{array}$ & - \\
\hline Changes of the Number of Judges & - & $\begin{array}{l}1.386 \\
(1.50)\end{array}$ & $\begin{array}{l}1.284 \\
(1.34)\end{array}$ & - \\
\hline Real Income Improvements & - & $\begin{array}{l}1.695^{* *} \\
(2.96)\end{array}$ & - & - \\
\hline $\begin{array}{l}\text { Real Constancy of the Budget of the High- } \\
\text { est Court }\end{array}$ & - & $\begin{array}{l}-0.495 \\
(0.99)\end{array}$ & $\begin{array}{r}0.769 \\
(1.53)\end{array}$ & - \\
\hline $\begin{array}{l}\text { Number of Changes of Relevant Articles } \\
\text { of the Constitution }\end{array}$ & - & $\begin{array}{r}1.309 \\
(1.02)\end{array}$ & $\begin{array}{r}0.833 \\
(0.64)\end{array}$ & - \\
\hline Implementation Deficit of Court's Rulings & - & $\begin{array}{l}0.095 \\
(0.10)\end{array}$ & $\begin{array}{l}0.194 \\
(0.21)\end{array}$ & - \\
\hline De iure Judicial Independence & - & - & - & $\begin{array}{l}-0.208 \\
(0.11)\end{array}$ \\
\hline $\begin{array}{l}\text { De facto Judicial Independence without } \\
\text { Real Income Improvements of Judges }\end{array}$ & - & - & - & $\begin{array}{c}4.953(*) \\
(1.98)\end{array}$ \\
\hline Real GDP per capita in 1980 (in \$ 1'000) & $\begin{array}{l}-0.125^{*} \\
(2.51)\end{array}$ & $\begin{array}{l}-0.176^{* *} \\
(3.20)\end{array}$ & $\begin{array}{l}-0.164 * * \\
(3.11)\end{array}$ & $\begin{array}{l}-0.190 * * \\
(2.99)\end{array}$ \\
\hline $\begin{array}{l}\text { Secondary School Attainment Rate in } 1980 \\
\text { (in \%) }\end{array}$ & $\begin{array}{l}0.056^{*} \\
(2.53)\end{array}$ & $\begin{array}{l}0.026 \\
(1.05)\end{array}$ & $\begin{array}{r}0.022 \\
(0.92)\end{array}$ & $\begin{array}{r}0.026 \\
(1.00)\end{array}$ \\
\hline $\begin{array}{l}\text { Real Gross Domestic Investment (in \% of } \\
\text { GDP), Average in 1980-1998 }\end{array}$ & $\begin{array}{l}0.113^{* *} \\
(3.50)\end{array}$ & $\begin{array}{c}0.164 * * \\
(5.233)\end{array}$ & $\begin{array}{c}0.164 * * \\
(4.99)\end{array}$ & $\begin{array}{c}0.158^{* *} \\
(4.81)\end{array}$ \\
\hline Constant & -1.829 & -4.435 & -4.063 & -3.574 \\
\hline$\overline{\mathrm{R}}^{2}$ & 0.564 & 0.553 & 0.523 & 0.610 \\
\hline SER & 1.792 & 1.815 & 1.875 & 1.725 \\
\hline J. -B. & 4.566 & 2.128 & 1.975 & 1.283 \\
\hline$\chi^{2}$-statistic & $16.816^{* *}$ & $20.763 * *$ & $13.068(*)$ & - \\
\hline
\end{tabular}

For notes see Table 2 . The $\chi^{2}$-statistic is a test on the hypothesis that all indicators of judicial independence in one equation are jointly equal to zero. The estimation results for the Dummy for Georgia are not reported.

In the next step, we reconstruct the index by excluding real income improvements of judges and estimate the baseline regressions again. Column (4) of Table 3 hence corresponds to Col- 
umn (5) of Table 2. ${ }^{14}$ It is obvious from these results that the positive impact of de facto JI on economic growth is qualitatively not affected by the inclusion or exclusion of the real income improvements of judges. Quantitatively, the impact of de facto JI on GDP growth increases however as does its statistical significance. The control variables are only slightly affected.

These results underline the above conjecture: Judicial independence in some countries may solely be written down in legal documents without actually keeping up judicial independence de facto. Judicial independence is important for economic growth, but it cannot be simply obtained by changes in law. It must be backed up by actually living judicial independence. Moreover, de facto JI is not simply dominated by real income improvements of judges such that the results do not appear to be due to a reversed causation effect. Nevertheless, it proves to be relatively important for de iure JI to have a positive impact on GDP growth if the highest court's procedures are specified in the constitution. It could be argued that it is the necessary condition for judicial independence anyway. In the remainder of the paper, we will however not elaborate the importance of the constitutional specification of procedures further, but instead leave it to future research. We focus on the robustness of the de facto JI. De iure JI is thus only used as a control variable in the concluding sections.

\subsection{Robustness to Additional Variables}

As usual, the impact of the de facto JI indicator may be reflecting third variables that are not yet included in the estimation equation. Put differently, an omitted variable bias might influence the estimation results. In order to check the robustness of the results to the inclusion of other variables, average government consumption in percent of GDP, openness, average population growth, average inflation as additional economic controls and the legal origin of the countries, several indicators of economic freedom that include some assessment of judicial independence, ${ }^{15}$ an indicator of the lack of political instability and the age of the constitution as additional political/institutional controls are included in the econometric model. As a

14. Like in Table 2, the respective regression is performed with only 57 observations in contrast to the other three regressions in Table 3 which are on the basis of 66 countries.

15. It looks strange to include the economic freedom indicators in addition to the indices of de iure and de facto judicial independence if the former already includes some aspects of judicial independence. However, it has to be noted that the judicial independence indices capture this particular effect of components included in the economic freedom indicator properly by using multivariate regression analysis. The measured effect of the economic freedom indicators is thus only that of the other components excluding judicial independence. An alternative method would be the explicit exclusion of that specific component from the economic freedom indicators. Both methods are equivalent. 
workhorse equation to proceed, column (4) of Table 3 is used. This equation has proved to be robust to outliers and it contains the revised de facto JI index without real income improvements of judges. The results of that exercise are presented in Table 4.

Table 4: Regressions of GDP Growth per Capita from 1980 to 1998 on Judicial Independence and Controls, Robustness Tests

\begin{tabular}{lcccc}
\hline Variables & $(\mathbf{1})$ & $(\mathbf{2})$ & $\mathbf{( 3 )}$ & $\mathbf{( 4 )}$ \\
\hline De iure Judicial Independence & -0.323 & -0.122 & $-3.525^{*}$ & -0.455 \\
& $(0.16)$ & $(0.06)$ & $(2.30)$ & $(0.23)$ \\
$\begin{array}{l}\text { De facto Judicial Independence } \\
\text { without Real Income Improve- }\end{array}$ & $5.150\left(^{*}\right)$ & $4.656(*)$ & $4.325\left(^{*}\right)$ & - \\
ments of Judges & $(2.00)$ & $(1.97)$ & $(1.81)$ & \\
$\begin{array}{l}\text { De facto Judicial Independence } \\
\text { without Real Income Improve- }\end{array}$ & - & & & $5.932^{*}$ \\
ments of Judges, but more than 3 & & - & & $(2.19)$ \\
components of it filled out. & & & & \\
\hline
\end{tabular}

\begin{tabular}{|c|c|c|c|c|}
\hline Additional Variables & & & & \\
\hline English Legal Origin & - & $\begin{array}{l}-0.244 \\
(0.35)\end{array}$ & - & - \\
\hline Socialist Legal Origin & - & $\begin{array}{l}-1.114 \\
(1.27)\end{array}$ & - & - \\
\hline French Legal Origin & - & $\begin{array}{c}-1.046(*) \\
(1.71)\end{array}$ & - & - \\
\hline German Legal Origin & - & $\begin{array}{c}-0.295 \\
(0.41)\end{array}$ & - & - \\
\hline$\chi^{2}$-statistic: Legal Origin & - & 9.001 & - & - \\
\hline Lack of Political Instability & - & - & $\begin{array}{l}0.272 \\
(0.46)\end{array}$ & - \\
\hline Age of the Constitution & - & - & $\begin{array}{c}0.015^{* *} \\
(3.35)\end{array}$ & - \\
\hline $\begin{array}{l}\text { Government Consumption (in \% } \\
\text { of GDP), Openness (in \% of } \\
\text { GDP), Average Population } \\
\text { Growth, 1980-1998, Inflation }\end{array}$ & yes & no & no & no \\
\hline $\begin{array}{l}\chi^{2} \text {-statistic: Economic Vari- } \\
\text { ables }\end{array}$ & 5.000 & - & - & - \\
\hline Economic Freedom Indicators & no & no & yes & no \\
\hline $\begin{array}{l}\chi^{2} \text {-statistic: Economic Freedom } \\
\text { Indicators }\end{array}$ & - & - & $29.131 * *$ & - \\
\hline$\overline{\mathrm{R}}^{2}$ & 0.619 & 0.601 & 0.590 & 0.624 \\
\hline SER & 1.710 & 1.745 & 1.033 & 1.747 \\
\hline J. -B. & 8.263 & 0.275 & 1.002 & 2.716 \\
\hline Observations & 57 & 57 & 35 & 51 \\
\hline
\end{tabular}

For notes see Table 2. Results for the standard controls, the single economic variables, the single indicators of economic freedom, the dummy for Georgia and constant are not reported. 
Only the results for the two indexes of JI are exhibited in all equations. With the exception of legal origin, lack of political instability and the age of the constitution, the results for control variables are not presented. Only the $\chi^{2}$-statistics on joint significance of the additional economic controls and the economic freedom indicators are reported in order to assess the validity of the estimation results. It should be noted as well that the number of observations is reduced to 35 countries if the age of the constitution and the economic freedom indicators are used such that the degrees of freedom in that regression are reduced to the lowest justifiable number.

None of the additional economic variables has a single significant impact on GDP growth. In addition, the hypothesis that they are not jointly significant cannot be rejected on any conventional significance level. As the results in column (1) of Table 4 indicate, the impact of de facto JI remains robust to the inclusion of additional economic variables. The same holds with respect to the legal origin variables. Judicial independence may be the result of the legal and political environment in general. For example, judicial independence may depend upon the legal tradition of a country such that judicial independence is less pronounced, say, in countries with a Socialist or French legal origin. The effect of judicial independence measured in the regressions above may then only reflect the impact of legal origin. In order to capture that impact, the respective variables reported by La Porta et al. (1999) are included in the regressions. These are five dummy variables taking on the value of one in the case of English, French, Socialist, German or Scandinavian legal origin, respectively. Because these dummies together are perfectly collinear, Scandinavian legal origin is used as the reference group. The consideration of these additional institutional variables does not change the results neither of the JI indicators nor of the economic controls. The legal origin dummies jointly are not significantly different from zero according to the $\chi^{2}$-statistics reported in Table 4 .

Like judicial independence might be the result of the legal origin, it may also be shaped by political stability. It is easy to grant judges de facto judicial independence in quiet times, but much more difficult in cases of political turmoil. Since political turmoil is usually leading to economic crises (and vice versa), the positive impact of JI on economic growth would simply reflect the impact of political stability, and an omitted variable bias would result. Political stability is controlled for by a variable on the lack of political instability provided by the World Bank (2001). According to the results in Column (3) of Table 4, the lack of political instability is not significantly different from zero although it has the expected positive sign. However, the indicators of economic freedom are jointly significant on the 1 percent level as 
the $\chi^{2}$-statistics indicate. In addition, the age of the constitution has a highly significant positive impact of GDP growth. The index of de facto JI is measuring the long term experience of a country with respect to judicial independence. It should thus be expected that countries with an older constitution have also established JI for a longer time period and thus arrive at higher index values. Introducing all these variables together, the impact of de facto JI on economic growth remains positive and significant on the 10 percent level. Despite the theoretical arguments for an impact of the additional institutional variables on $\mathrm{JI}$, de facto JI has a robust and significant positive influence on economic growth. ${ }^{16}$

Given these rather robust results, the reliability of the constructed JI indicators may raise the only remaining doubts on the validity of the estimation results. A final test of robustness is thus concerned with a check as to how robust the impact of judicial independence, in particular the de facto JI indicator, is to changes in the definition of that variable. As noted above, countries were only included in the sample of the de facto indicator if they replied to at least three of the eight components comprising de facto JI. This decision is of course arbitrary. We could as well have demanded each other number between 1 and 8 . We therefore change our reservation number of replies to that question as a robustness test. A glance at Appendix 3 reveals that the countries providing replies to only 3 components are already the strangest countries in the ranking. For example, the two highest ranking countries Armenia and Kuwait do not have a strong record for judicial independence, while the Netherlands and the Czech Republic may be ranked too low according to usual prejudice.

Column (4) of Table 4 therefore reports the specification of the baseline model, like in column (4) of Table 3, that is robust to outliers. It contains as well the corrected index of de facto JI without real income improvements of judges, but the index is based on at least 4 components of that index. The number of observations is then reduced to only 51. It is again not necessary to describe these results in more detail. Of course, the point estimates of the single variables change. This is however no surprise given the changes in sample size and in the indicator for de facto JI. The latter impact turns out to be even stronger in statistical and economic terms: Significance levels are slightly higher and the size of the coefficient is higher as well. The inclusion of countries incompletely answering to the survey in the de facto indicator obvi-

16. In addition to the political and legal variables reported, robustness tests were performed using indicators of ethnic/linguistic fractionalization of a country and of the number of coups. The de facto indicator of judicial independence remained robust to any of these additional specifications not reported here. 
ously weakens the results. All in all, this is strong evidence for a positive impact of judicial independence on economic growth.

\section{Conclusions and Open Questions}

Using two new indicators of judicial independence, a de iure and a de facto indicator that are obtained from a survey among experts in 71 countries, we have analyzed the impact of judicial independence on economic growth. While de iure judicial independence does not have a clear impact on economic growth, de facto JI positively influences real GDP growth per capita in a sample of 57 countries. This distinction between de iure and de facto JI indicates that it does not suffice to write JI in legal documents. It is necessary to shape JI by additional informal procedures that may be accompanied and enforced by informal social sanctions. Issues like the average term length of judges, its deviation from the term lengths to be expected based on legal documents, effective removals of judges before the end of their terms as well as a secure income for the judges appear to be more important for economic growth than de iure independence. Only the constitutional specification of the court's procedures as one aspect of de iure JI proves to be significant and positive. The impact of de facto JI on economic growth is robust to outliers, to the inclusion of several additional economic, legal and political control variables and to the construction of the index. It can thus be concluded that judicial independence matters for economic growth. That de facto JI appears to have a stronger impact on GDP growth than de iure JI finds its analogue in the central bank literature according to which de facto CBI is a better predictor of inflation than de iure CBI (see Section 3).

Several potential extensions of the approach in this paper have been mentioned in the passing. The first is a closer inspection of the components of de iure JI and their robustness on the inclusion of other economic and institutional factors. It is quite interesting to note that the constitutional specification of procedures, but none of the other components of de iure JI affect economic growth. The scope of this paper is too limited to study this effect and potential interaction effects with other components in more detail. It must be left to future research. Another natural extension is focusing on the weights attached to the different components in the construction of both indexes. This might range from arguably core features of JI being attached a higher weight to indexes constructed from factor analysis. It should be noted however that both, attaching higher weights to a selection of components of JI that one thinks are more important as well as indexes based on factor analysis can be supposed to increase the explanatory power of JI in statistical terms. Compared to that alternative procedure, our approach is relatively conservative and less vulnerable to criticism. 
Another extension, suggested to us by a referee, is a variation of the question and thus the dependent variable analyzed. One of the transmission channels by which JI may influence GDP growth is private investment either in physical or human capital. Both variables are included as explanatory controls to explain GDP growth in this model. Again, the analysis of that question is beyond the scope of this paper in particular because it directly leads to a whole bunch of further interesting questions. Similarly, the discussion about legal origin in the finance literature appears to warrant additional investigation after the impact of legal origin on economic growth is strongly dominated by de facto JI.

In future studies, it might also be interesting to test for the independence not of constitutional courts, but of commercial courts. It could be the case that private investors are primarily interested in how commercial and not constitutional disputes are resolved. Further, one might want to fine-tune some of the variables of the de facto indicator: right now, any deviation between expected and effective term-length will lead to a reduction of a country's score. It, however, makes sense to distinguish between politically motivated and other changes. A divergence might simply be due to a judge dying before the end of his term. This distinction could also be made with regard to some other variables.

It was mentioned above that there are some similarities between JI and central bank independence (CBI) that deserve further research. In the CBI-literature, the degree of independence has been taken as an exogenous variable. The explanation of the different degrees of the de facto-independence remains a clear deficit of the theory (Berger, 1997). But it almost suggests itself to hypothesize that an independent judiciary is a precondition for an independent central bank - and thus to endogenize CBI (see also Voigt, 2002). This hypothesis could, of course, be extended to other independent government agencies such as antitrust agencies, statistical offices etc. It could, of course, also be the case that there is a high correlation between the two but that the (de facto) CBI is not caused by the (de facto) JI because a third variable, like culture, helps to explain both (see, e.g., Hayo, 1998).

\section{Acknowledgements}

The authors would like to thank Anne van Aaken, Ivan Baron Adamovich, Helge Berger, Reiner Eichenberger, James Gwartney, Jakob de Haan, Bernd Hayo, Witold Henisz, Gerald Hosp, Bruno Jeitziner, Wolfgang Kasper, Phil Keefer, Gebhard Kirchgässner, Henner Kleinewefers, Robert Nef, Martin Paldam, Philip Pettit, Martin Raiser, Eli Salzberger, Christoph Schaltegger, Oliver Volckart, Zane Spindler, and two anonymous referees for valuable com- 
ments. Research assistance by Anja Sokolow and Lorena Jaume-Palasí often went far beyond the required and is gratefully acknowledged. The usual disclaimer applies.

\section{Appendix 1: Text of the questionnaire combined with coding used \\ Making Promises Credible - \\ Independent Courts as a Proxy for the Rule of Law \\ QUESTIONNAIRE}

\section{Please return to:}

Prof. Dr. Stefan Voigt

Economic Policy, Economics

Ruhr-University Bochum

D-44780 Bochum

Germany

Dear Reader,

This research project is an attempt to make judicial independence measurable and thus comparable between countries. I would be grateful if you could help me with your knowledge concerning the country on which you are an expert. I would appreciate if you could (a) answer the following questions, and (b) could indicate good sources to get the desired information (primary as well as secondary).

If you are interested, I would be pleased to keep you informed on the progress concerning the indicator. In that case, please provide me with your address. Of course, the easiest way to return the questionnaire is by e-mail.

Thank you very much for your help. Yours sincerely

Stefan Voigt 


\section{Country for which information is provided:}

\section{A de iure measure for court independence}

(1) Is the highest court mentioned in the constitution? NO

a. Are its competencies enumerated in the constitution?

b. Are its procedures specified in the constitution?

c. Is access to the highest court specified in the constitution?

d. Are the arrangements concerning the members of the highest court enumerated in the constitution?

aa. Is the term length specified in the constitution?

(1/16) YES ( ) NO

bb. Is the number of judges specified in the constitution?

(1/16) YES ( ) NO

A GOOD SOURCE FOR MORE DETAILED INFORMATION IS

(2) How difficult is it to amend the constitution?

a. Is a majority necessary that is above that necessary for changing ordinary legislation?

(1) YES ( ) NO

b. How many branches of government have to agree?

(1/4) $1 ; \quad(1 / 2) \quad 2$; $(3 / 4) 3$

c. Are majority decisions necessary at different points in time?

(1/4) YES ( ) NO

* Note on coding concerning this question: The sum of $\mathrm{b}$ and $\mathrm{c}$ provided that $\mathrm{a}$ is answered in the affirmative

A GOOD SOURCE FOR MORE DETAILED INFORMATION IS

17 The numbers in parantheses are the codings used; these were not part of the questionnaire as sent to the country experts. 
(3) How are the members of the highest court elected/nominated? (PLEASE TICK THE APPROPRIATE LETTER)

a. Judges are nominated and elected by one or more members of the executive

b. Judges are nominated by one or more members of the executive and are elected by parliament (or a committee thereof).

c. Judges are nominated by one or more members of the executive and are elected by the judiciary.

d. Judges are nominated and elected by parliament (or a committee thereof).

e. Judges are nominated by parliament (or a committee thereof) and are elected by one or more members of the executive.

f. Judges are nominated by parliament (or a committee thereof) and are elected by the judiciary.

g. Judges are nominated and elected by the judiciary.

h. Judges are nominated by the judiciary and are elected by one or more members of the executive.

i. Judges are nominated by the judiciary and are elected by parliament (or a committee thereof).

j. Judges are nominated by the judiciary, the legislature, or the executive and are elected by actors not representing any government branch (academics, the public at large

\begin{tabular}{|c|c|c|c|c|}
\hline & & \multicolumn{3}{|c|}{$\begin{array}{c}\text { Competence to elect/appoint members } \\
\text { of highest court }\end{array}$} \\
\hline & & Executive & Legislature & Judiciary \\
\hline \multirow{3}{*}{$\begin{array}{l}\text { Competence to } \\
\text { nominate } \\
\text { members of } \\
\text { highest court }\end{array}$} & Executive & 0 & $1 / 3$ & $2 / 3$ \\
\hline & Legislature & $1 / 3$ & 0 & $2 / 3$ \\
\hline & \begin{tabular}{|l|} 
Judiciary \\
\end{tabular} & $2 / 3$ & $2 / 3$ & 1 \\
\hline
\end{tabular}


(4) What is the legal term length of the judges on the highest court?

NUMBER OF YEARS

In comparison, parliament's election period in number of years

Concerning legal term length, emphasis in the institutional arrangement is usually either on a specification in number of years or on a fixed retirement age. We thus need two coding scales. Here they are:

Term of office(too) coding

$\geq 12$ years $\quad 1,0$

$10 \leq$ too $<12 \quad 0,8$

$8 \leq$ too $<10 \quad 0,6$

$6 \leq$ too $<8 \quad 0,4$

$4 \leq$ too $<6 \quad 0,2$

$4>$ too $\quad 0,0$

Often, judges are appointed rather later in their careers. Early and mandatory retirement is hypothesized to constrain ji because judges could be less daring during their first couple of years in office. We used the following coding:

$\underline{\text { Too coding }}$

for life $\quad 1,0$

Mandatory retirement $(\mathrm{mr}) \geq 75$ years 1,0

$65 \leq \mathrm{mr}<75 \quad 0,8$

$65>\mathrm{mr} \quad 0,6$.

A GOOD SOURCE FOR MORE DETAILED INFORMATION IS

(5) Can judges be reelected?

(0) YES ( ) NO

A GOOD SOURCE FOR MORE DETAILED INFORMATION IS

(6) How can judges be removed from office? (PLEASE TICK THE APPROPRIATE LETTER) 
a. only by judicial procedure; $\quad 1$

b. by decision of one or more members of the executive; $\quad 0$

c. by decision of parliament (or a committee thereof); 0

d. by joint decision of one or more members of the executive and of parliament (or a committee thereof). $1 / 2$.

A GOOD SOURCE FOR MORE DETAILED INFORMATION IS

(7) Is there a measure against income reduction of judges? Is there a mechanism securing $\begin{array}{ll}\text { adjustment in real terms? } & \text { (1) YES ( ) NO }\end{array}$

A GOOD SOURCE FOR MORE DETAILED INFORMATION IS

(8) Are the judges paid adequately?

a. Are they paid more than university professors? (1/3) YES ( ) NO

b. Are they paid more than an average private lawyer? (1/3) YES ( ) NO

c. Are they paid as well as the minister of justice? (1/3) YES ( ) NO

A GOOD SOURCE FOR MORE DETAILED INFORMATION IS

(9) Who has the possibility to access the highest court?

a. Individuals in any case relevant to the constitution and with which they are personally concerned.

b. Individuals, but only in a subset of cases relevant to the constitution (such as human rights) $1 / 2$.

$\begin{array}{ll}\text { c. Only other government branches. } & 0\end{array}$

A GOOD SOURCE FOR MORE DETAILED INFORMATION IS

(10) Is there a general rule allocating the responsibility concerning incoming cases to specific judges?

(1) YES ( ) NO

(or does the chief justice have discretion on the allocation of cases?) ( ) YES ( ) NO 
(11) Does the constitution (or the law establishing the highest court) preview the power of constitutional review?

(1) YES ( ) NO

Are there any limits to it (e.g., only before a law has been promulgated?)

( ) YES ( ) NO

\section{A GOOD SOURCE FOR MORE DETAILED INFORMATION IS}

(12) Does the highest court have to publish
(a) the main reasons for a decision
(1/3) YES ( ) NO
(b) an extended proof?
(1/3) YES ( ) NO
(12) Are dissenting opinions published regularly?
(1/3) YES ( ) NO

\section{A de facto measure for court independence}

(13) What has been the effective average term length of judges since the respective legal foundations have been passed? IN NUMBER OF YEARS

For coding, the number of years was multiplied by 0.05 .

a. does it deviate from the average term length

to be expected by the legal foundations?

(0) YES ( ) NO

b. How many judges have been removed from office before end of term? NUMBER

For coding, any positive number led to a zero-coding.

A GOOD SOURCE FOR MORE DETAILED INFORMATION IS

(14) How many times has the number of judges been changed since 1960? NUMBER

The answers were coded using the following table:

Number of changes Coding

$0 \quad 1,0$

$1-2 \quad 0,8$ 


$\begin{array}{ll}3-4 & 0,6 \\ 5-6 & 0,4 \\ 7-8 & 0,2 \\ \text { more } & 0,0\end{array}$

A GOOD SOURCE FOR MORE DETAILED INFORMATION IS

(15) Has the income of judges remained at least constant in real terms since 1960 ?

(1) YES ( ) NO

A GOOD SOURCE FOR MORE DETAILED INFORMATION IS

(16) Has the budget of the highest court remained

at least constant in real terms since 1960 ?

(1) YES ( ) NO

A GOOD SOURCE FOR MORE DETAILED INFORMATION IS

(17) How often have the relevant articles of the Constitution (or the law on which the highest court is based) been changed since 1960 ?

NUMBER OF CHANGES

The answers were coded according to the key used for variable 14.

A GOOD SOURCE FOR MORE DETAILED INFORMATION IS

(18) In how many cases has one of the other government branches remained inactive when its action was necessary for a decision to become effective?

NUMBER OF CASES

The answers were again coded according to the key used for variable 14 .

A GOOD SOURCE FOR MORE DETAILED INFORMATION IS

General comments (please feel free to make any comment): 


\section{Appendix 2: The de iure Index}

In the following table, the de iure index is presented in the rank order that emerged as a result of the coding:

\begin{tabular}{|c|c|c|c|c|c|c|c|}
\hline Rank & Country & $\begin{array}{l}\text { Index } \\
\text { Value }\end{array}$ & $\begin{array}{l}\text { No. } \\
\text { Of } \\
\text { Var. }\end{array}$ & Rank & Country & $\begin{array}{l}\text { Index } \\
\text { Value }\end{array}$ & $\begin{array}{l}\text { No. } \\
\text { Of } \\
\text { Var. }\end{array}$ \\
\hline 1 & Colombia & 0,939 & 12 & 37 & Hungary & 0,651 & 11 \\
\hline 2 & Phillipines & 0,909 & 10 & 38 & Venezuela & 0,650 & 12 \\
\hline 3 & Brazil & 0,907 & 12 & 39 & Bahamas & 0,646 & 12 \\
\hline 4 & Georgia & 0,893 & 12 & 40 & Estonia & 0,641 & 11 \\
\hline 5 & Slovenia & 0,869 & 12 & 41 & France & 0,634 & 11 \\
\hline 6 & Singapore & 0,851 & 12 & 42 & Netherlands & 0,631 & 12 \\
\hline 7 & Russia & 0,845 & 11 & 43 & Armenia & 0,629 & 12 \\
\hline 8 & Botswana & 0,841 & 12 & 44 & India & 0,629 & 12 \\
\hline 9 & Ecuador & 0,835 & 12 & 45 & Japan & 0,622 & 12 \\
\hline 10 & Greece & 0,833 & 10 & 46 & Jordan & 0,615 & 8 \\
\hline 11 & Belgium & 0,825 & 10 & 47 & Korea, South & 0,607 & 12 \\
\hline 12 & Australia & 0,817 & 11 & 48 & Sweden & 0,605 & 10 \\
\hline 13 & Cyprus & 0,817 & 12 & 49 & Trinidad/ Tobago & 0,596 & 10 \\
\hline 14 & Mexico & 0,804 & 12 & 50 & Taiwan & 0,575 & 12 \\
\hline 15 & Nepal & 0,799 & 12 & 51 & Kuwait & 0,574 & 10 \\
\hline 16 & Mauritius & 0,797 & 11 & 52 & Croatia & 0,570 & 11 \\
\hline 17 & Italy & 0,793 & 12 & 53 & Slovakia & 0,569 & 12 \\
\hline 18 & Paraguay & 0,781 & 8 & 54 & Spain & 0,551 & 12 \\
\hline 19 & Denmark & 0,779 & 11 & 55 & Romania & 0,548 & 7 \\
\hline 20 & Chile & 0,778 & 9 & 56 & Kazakhstan & 0,538 & 11 \\
\hline 21 & Pakistan & 0,765 & 12 & 57 & Portugal & 0,530 & 10 \\
\hline 22 & Czech Republic & 0,761 & 12 & 58 & Ivory Coast & 0,507 & 11 \\
\hline 23 & South Africa & 0,761 & 11 & 59 & Guatemala & 0,499 & 11 \\
\hline 24 & Austria & 0,733 & 11 & 60 & Montenegro & 0,465 & 11 \\
\hline 25 & Germany & 0,729 & 12 & 61 & Ghana & 0,464 & 7 \\
\hline 25 & Fiji Islands & 0,729 & 11 & 62 & Switzerland & 0,459 & 12 \\
\hline 27 & Kenya & 0,709 & 12 & 63 & Azerbaijan & 0,451 & 10 \\
\hline 28 & Egypt & 0,708 & 12 & 64 & Lithuania & 0,447 & 11 \\
\hline 29 & Poland & 0,693 & 11 & 65 & Mozambique & 0,441 & 12 \\
\hline 30 & USA & 0,685 & 12 & 66 & China & 0,406 & 12 \\
\hline 31 & Costa Rica & 0,685 & 12 & 67 & Bulgaria & 0,397 & 12 \\
\hline 32 & Namibia & 0,684 & 12 & 68 & Vanuatu & 0,377 & 10 \\
\hline 33 & Canada & 0,681 & 10 & 69 & Malaysia & 0,313 & 8 \\
\hline 34 & Turkey & 0,678 & 12 & 70 & Morocco & 0,275 & 5 \\
\hline 35 & Argentina & 0,665 & 12 & 71 & Tanzania & 0,265 & 12 \\
\hline 36 & Israel & 0,663 & 12 & & & & \\
\hline
\end{tabular}




\section{Appendix 3: The de facto Index}

Ranking and scores according to the de facto indicator:

\begin{tabular}{|c|c|c|c|c|c|c|c|}
\hline Rank & Country & $\begin{array}{l}\text { Index } \\
\text { Value }\end{array}$ & $\begin{array}{l}\text { No. } \\
\text { Of } \\
\text { Var. }\end{array}$ & Rank & Country & $\begin{array}{l}\text { Index } \\
\text { Value }\end{array}$ & $\begin{array}{l}\text { No. } \\
\text { Of } \\
\text { Var. }\end{array}$ \\
\hline 1 & Armenia & 1,000 & 3 & 33 & Jordan & 0,560 & 5 \\
\hline 1 & Kuwait & 1,000 & 3 & 34 & Guatemala & 0,550 & 7 \\
\hline 3 & Switzerland & 0,943 & 7 & 35 & USA & 0,546 & 6 \\
\hline 4 & Turkey & 0,933 & 6 & 36 & Pakistan & 0,525 & 8 \\
\hline 5 & Costa Rica & 0,920 & 5 & 37 & Mozambique & 0,520 & 5 \\
\hline 6 & Austria & 0,900 & 4 & 37 & Nepal & 0,520 & 5 \\
\hline 6 & Japan & 0,900 & 4 & 39 & Greece & 0,500 & 4 \\
\hline 9 & South Africa & 0,867 & 6 & 40 & Brazil & 0,494 & 8 \\
\hline 10 & Taiwan & 0,863 & 8 & 41 & Netherlands & 0,467 & 3 \\
\hline 11 & Israel & 0,860 & 5 & 42 & Bahamas & 0,450 & 4 \\
\hline 12 & Italy & 0,858 & 6 & 43 & Fiji Islands & 0,436 & 7 \\
\hline 13 & Georgia & 0,850 & 6 & 44 & Lithuania & 0,433 & 6 \\
\hline 14 & Australia & 0,819 & 8 & 45 & Slovenia & 0,431 & 8 \\
\hline 15 & Denmark & 0,813 & 6 & 46 & Singapore & 0,421 & 7 \\
\hline 16 & Belgium & 0,800 & 8 & 47 & Botswana & 0,414 & 7 \\
\hline 16 & Germany & 0,800 & 6 & 48 & Ecuador & 0,400 & 8 \\
\hline 16 & Hungary & 0,800 & 8 & 48 & Venezuela & 0,400 & 4 \\
\hline 19 & France & 0,780 & 5 & 50 & Trinidad/ Tobago & 0,388 & 4 \\
\hline 20 & Spain & 0,750 & 8 & 51 & China & 0,370 & 5 \\
\hline 21 & Cyprus & 0,743 & 7 & 52 & Argentina & 0,333 & 6 \\
\hline 22 & Phillipines & 0,731 & 8 & 53 & Vanuatu & 0,320 & 5 \\
\hline 23 & India & 0,708 & 6 & 54 & Slovakia & 0,319 & 8 \\
\hline 24 & Mexico & 0,707 & 7 & 55 & Ghana & 0,300 & 3 \\
\hline 25 & Portugal & 0,706 & 8 & 56 & Malaysia & 0,270 & 5 \\
\hline 26 & Estonia & 0,700 & 8 & 57 & Egypt & 0,240 & 5 \\
\hline 26 & Sweden & 0,700 & 5 & 58 & Kenya & 0,175 & 6 \\
\hline 28 & Croatia & 0,657 & 7 & 59 & Czech Republic & 0,167 & 3 \\
\hline 29 & Paraguay & 0,600 & 3 & 60 & Bulgaria & 0,133 & 6 \\
\hline 30 & Korea, South & 0,588 & 8 & 60 & Russia & 0,133 & 6 \\
\hline 31 & Chile & 0,575 & 4 & 62 & Montenegro & 0,100 & 4 \\
\hline 32 & Colombia & 0,571 & 7 & & & & \\
\hline
\end{tabular}

$\mathrm{N}=62$; mean $=0,591$; standard deviation $=0,242$. 


\section{Bibliography}

Barro, R., Gordon, D., 1983. Rules, Discretion, and Reputation in a Positive Model of Monetary Policy. Journal of Monetary Economics 12, 101-21.

Berger, H., 1997. Die aktuelle Debatte um Zentralbankunabhängigkeit: Theoretische und empirische Fragen. Zeitschrift für Unternehmensgeschichte 41, 89-111.

Berger, H., Haan, J. de, Eijffinger, S., 2001. Central Bank Independence: An Update of Theory and Evidence. Journal of Economic Surveys 15, 3-40.

Cukierman, A., 1992, Central Bank Strategy, Credibility, and Independence. MIT Press, Cambridge.

Cukierman, A., Webb, S., Neyapti, B., 1992. Measuring the Independence of Central Banks and Its Effects on Policy Outcomes. The World Bank Economic Review 6, 353-98.

Debelle, G., Fischer, S., 1995, How Independent Should a Central Bank Be? In: Fuhrer, J.C., (Ed.), Goals, Guidelines and Constraints Facing Monetary Policymakers, Federal Reserve Bank of Boston, Conference Series No. 38, Boston, pp. 195-221.

Feld, L.P., Matsusaka, J.G., 2003. Budget Referendums and Government Spending: Evidence from Swiss Cantons. Journal of Public Economics, forthcoming.

Ferejohn, J., Weingast, B., 1992. A Positive Theory of Statutory Interpretation. International Review of Law and Economics 12, 263-79.

Freedom House, 2001, Freedom House Country Ratings. www.freedomhouse.org/ratings/index.htm.

Gely, R., Spiller, P., 1990. A Rational Theory of Supreme Court Statutory Decisions with Applications to the State Farm and Grove City Cases. Journal of Law, Economics, and Organization 6, 263-300.

Grilli, V., Masciandaro, D., Tabellini, G., 1991. Political and Monetary Institutions and Public Financial Policies in the Industrial Countries. Economic Policy 13, 341-92.

Gwartney, J., Lawson, R., Samida D., 2000, Economic Freedom of the World: 2000 Annual Report. The Fraser Institute et al.., Vancouver et. al.

Haan, J. de, Sturm, J.E., 2000. On the Relationship between Economic Freedom and Economic Growth. European Journal of Political Economy 16, 215-241.

Hayo, B., 1998. Inflation Culture, Central Bank Independence and Price Stability, European Journal of Political Economy 14, 241-263.

Hayo, B., Hefeker, C., 2002. Reconsidering Central Bank Independence. European Journal of Political Economy 18, 653-674.

Henisz, W., 2000. The Institutional Environment for Economic Growth. Economics and Politics 12, 131.

Heritage Foundation, Wall Street Journal, 2002, Index of Economic Freedom, www.heritage.org/index/. 
Heston, A., Summers, R., Aten, B., 2001, Penn World Table Version 6.0. Center for International Comparisons at the University of Pennsylvania (CICUP), December 2001.

Keefer, P., Stasavage, D., 2001, The Limits of Delegation: Veto Players, Central Bank Independence and the Credibility of Monetary Policy. Mimeo, LSE, London.

Kydland, F., Prescott, E., 1977. Rules Rather than Discretion: The Inconsistency of the Optimal Plans. Journal of Political Economy 85, 473-91.

La Porta, R., Lopez-de-Silanes, F., Shleifer, A., Vishny, R., 1999. The Quality of Government. Journal of Law, Economics and Organization 15, 222-279.

Macey, J.R, 1992. Separated Powers and Positive Political Theory: The Tug of War Over Administrative Agencies. Georgetown Law Journal 80, 671-703.

McCubbins, M., Noll, R., Weingast, B., 1987. Administrative Procedures as Instruments of Political Control. Journal of Law, Economics and Organization 3, 243-77.

McCubbins, M., Noll, R., Weingast, B., 1989. Structure and Process, Politics and Policy: Administrative Arrangements and the Political Control of Agencies. Virginia Law Review 75, 431-82.

McCubbins, M., Schwartz, T., 1984. Congressional Oversight Overlooked: Police Patrols versus Fire Alarms. American Journal of Political Science 28, 165-79.

Moe, T.M., 1990. Political Institutions: The Neglected Side of the Story. Journal of Law, Economics, and Organization 6, 213-53.

Moser, P., 2000, The Political Economy of Democratic Institutions. Edward Elgar, Cheltenham.

Smithey, Sh., Ishiyama, J., 2000. Judicious Choices: Designing Courts in Post-Communist Politics. Communist and Post-Communist Studies 33, 163-182.

Voigt, S., 1999. Implicit Constitutional Change - Changing the Meaning of the Constitution Without Changing the Text of the Document. European Journal of Law and Economics 7, 197-224.

Voigt, S., 2002. Die unabhängige Justiz - eine vernachlässigte Determinante zur Erklärung der Zentralbankunabhängigkeit?. Schmollers Jahrbuch 122, 207-25.

Weingast, B., 1993. Constitutions as Governance Structures: The Political Foundations of Secure Markets. Journal of Institutional and Theoretical Economics (JITE) 149, 286-311.

World Bank, 2001, Aggregate Governance Indicators. http://www.worldbank.org/resarch/ growth/corrupt_data.htm.

Zeppos, N.S., 1993. Deference to Political Decisionmakers and the Preferred Scope of Judicial Review. Northwestern University Law Review 88, 296-371. 


\title{
CESifo Working Paper Series
}

\author{
(for full list see www.cesifo.de)
}

841 Robert Fenge and Martin Werding, Ageing and the Tax Implied in Public Pension Schemes: Simulations for Selected OECD Countries, January 2003

842 Robert Fenge and Martin Werding, Ageing and Fiscal Imbalances Across Generations: Concepts of Measurement, January 2003

843 Giovanni Andrea Cornia, The Impact of Liberalisation and Globalisation on Income Inequality in Developing and Transitional Economies, January 2003

844 Peter Fredriksson and Per Johansson, Program Evaluation and Random Program Starts, January 2003

845 Bernd Hayo and Matthias Wrede, Fiscal Equalisation: Principles and an Application to the European Union, January 2003

846 Syed M. Ahsan and Jaideep Oberoi, Inequality, Well-being and Institutions in Latin America and the Caribbean, January 2003

847 Chang Woon Nam and Doina Maria Radulescu, The Role of Tax Depreciation for Investment Decisions: A Comparison of European Transition Countries, January 2003

848 V. Bhaskar and Steinar Holden, Wage Differentiation via Subsidised General Training, January 2003

849 Paloma Lopez-Garcia, Labour Market Performance and Start-up Costs: OECD Evidence, January 2003

850 Christian Keuschnigg and Soren Bo Nielsen, Public Policy for Start-up Entrepreneurship with Venture Capital and Bank Finance, January 2003

851 Yin-Wong Cheung, Menzie D. Chinn, and Eiji Fujii, China, Hong Kong, and Taiwan: A Quantitative Assessment of Real and Financial Integration, January 2003

852 Gregory D. Hess, The Economic Welfare Cost of Conflict: An Empirical Assessment, February 2003

853 Douglas J. Cumming and Jeffrey G. MacIntosh, Comparative Venture Capital Governance. Private versus Labour Sponsored Venture Capital Funds, February 2003

854 Eckhard Janeba and John Douglas Wilson, Decentralization and International Tax Competition, February 2003

855 Tapio Palokangas, Capital Accumulation and Employment Cycles in a Model of Creative Destruction, February 2003 
856 Brendan Walsh, When Unemployment Disappears: Ireland in the 1990s, February 2003

857 Luis H. R. Alvarez and Erkki Koskela, A General Approach to the Stochastic Rotation Problem with Amenity Valuation, February 2003

858 Christian Schultz, Strategic Campaigns and Redistributive Politics, February 2003

859 Ernst Fehr and Joseph Henrich, Is Strong Reciprocity a Maladaptation? On the Evolutionary Foundations of Human Altruism, February 2003

860 Haizhou Huang, Dalia Marin, and Chenggang Xu, Financial Crisis, Economic Recovery and Banking Development in Former Soviet Union Economies, February 2003

861 Pedro Cardoso and Bernard M.S. van Praag, How Sustainable Are Old-age Pensions in a Shrinking Population with Endogenous Labour Supply?, February 2003

862 Volker Meier, Efficient Transfer of Aging Provisions in Private Health Insurance, February 2003

863 Edward Castronova, Theory of the Avatar, February 2003

864 Robert S. Chirinko, Hans van Ees, Harry Garretsen, and Elmer Sterken, Investor Protections and Concentrated Ownership: Assessing Corporate Control Mechanisms in the Netherlands, February 2003

865 Bernard M.S. van Praag and Pedro Cardoso, The Mix Between Pay-as-you-go and Funded Pensions and what Demography has to do with it, February 2003

866 Ernst Fehr, Urs Fischbacher, Bernhard von Rosenbladt, Jürgen Schupp, and Gert G. Wagner, A Nation-Wide Laboratory. Examining Trust and Trustworthiness by Integrating Behavioral Experiments into Representative Survey, February 2003

867 Frank Heinemann, The Inflationary Impact of Wage Indexation, February 2003

868 Eytan Sheshinski, Bounded Rationality and Socially Optimal Limits on Choice in a Self-Selection Model, February 2003

869 M. Hashem Pesaran, Estimation and Inference in Large Heterogenous Panels with Cross Section Dependence, February 2003

870 Luis H. R. Alvarez and Erkki Koskela, On the Tree-Cutting Problem under Interest Rate and Forest Value Uncertainty, February 2003

871 Norbert Berthold and Rainer Fehn, Unemployment in Germany: Reasons and Remedies, February 2003

872 Clemens Fuest, Bernd Huber, and Philipp Tilleßen, Tax Policy and Entrepreneurship in the Presence of Asymmetric Information in Capital Markets, February 2003

873 Eytan Sheshinski, Optimum and Risk-Class Pricing of Annuities, February 2003 
874 Willi Leibfritz, Paul O'Brien and Jean-Christophe Dumont, Effects of Immigration on Labour Markets and Government Budgets - An Overview, February 2003

875 M. Hashem Pesaran and Allan Timmermann, How Costly is it to Ignore Breaks when Forecasting the Direction of a Time Series?, February 2003

876 Thorvaldur Gylfason and Gylfi Zoega, Education, Social Equality and Economic Growth: A View of the Landscape, February 2003

877 Robin Boadway and Jean-François Tremblay, Public Economics and Startup Entrepreneurs, February 2003

878 Erkki Koskela and Roope Uusitalo, The Un-Intended Convergence: How the Finnish Unemployment Reached the European Level, February 2003

879 Robert Fenge and Volker Meier, Pensions and Fertility Incentives, February 2003

880 Eytan Sheshinski, Note on Income Taxation and Occupational Choice, February 2003

881 A B Atkinson, Income Inequality in OECD Countries: Data and Explanations, February 2003

882 Thomas Gehrig and Rune Stenbacka, Venture Cycles: Theory and Evidence, February 2003

883 Ralf Becker and Thomas Hellmann, The Genesis of Venture Capital - Lessons from the German Experience, March 2003

884 Eytan Sheshinski, Note on the Optimum Pricing of Annuities, March 2003

885 Paul De Grauwe and Magdalena Polan, Globalisation and Social Spending, March 2003

886 F. van der Ploeg, Do Social Policies Harm Employment and Growth?, March 2003

887 Mirjam van Praag, Initial Capital Constraints Hinder Entrepreneurial Venture Performance: An empirical analysis, March 2003

888 Bernard Steunenberg, Coordinating Sectoral Policymaking: Searching for Countervailing Mechanisms in the EU Legislative Process, March 2003

889 Eytan Sheshinski, Optimum Delayed Retirement Credit, March 2003

890 Frederick van der Ploeg, Rolling Back the Public Sector - Differential effects on employment, investment and growth, March 2003

891 Paul De Grauwe and Marc-Alexandre Sénégas, Monetary Policy in EMU when the Transmission is Asymmetric and Uncertain, March 2003

892 Steffen Huck and Kai A. Konrad, Strategic Trade Policy and the Home Bias in Firm Ownership Structure, March 2003 
893 Harry Flam, Turkey and the EU: Politics and Economics of Accession, March 2003

894 Mathias Hoffmann and Ronald MacDonald, A Re-examination of the Link between Real Exchange Rates and Real Interest Rate Differentials, March 2003

895 Badi H. Baltagi, Espen Bratberg, and Tor Helge Holmås, A Panel Data Study of Physicians' Labor Supply: The Case of Norway, March 2003

896 Dennis C. Mueller, Rights and Citizenship in the European Union, March 2003

897 Jeremy Edwards, Gains from Trade in Tax Revenue and the Efficiency Case for Trade Taxes, March 2003

898 Rainer Fehn and Thomas Fuchs, Capital Market Institutions and Venture Capital: Do They Affect Unemployment and Labour Demand?, March 2003

899 Ronald MacDonald and Cezary Wójcik, Catching Up: The Role of Demand, Supply and Regulated Price Effects on the Real Exchange Rates of Four Accession Countries, March 2003

900 R. Selten, M. Schreckenberg, T. Pitz, T. Chmura, and S. Kube, Experiments and Simulations on Day-to-Day Route Choice-Behaviour, April 2003

901 Stergios Skaperdas, Restraining the Genuine Homo Economicus: Why the Economy Cannot be Divorced from its Governance, April 2003

902 Yin-Wong Cheung, Menzie D. Chinn, and Antonio Garcia Pascual, What Do We Know about Recent Exchange Rate Models? In-Sample Fit and Out-of-Sample Performance Evaluated, April 2003

903 Mika Widgrén, Enlargements and the Principles of Designing EU - Decision-Making Procedures, April 2003

904 Phornchanok Cumperayot, Dusting off the Perception of Risk and Returns in FOREX Markets, April 2003

905 Kai A Konrad, Inverse Campaigning, April 2003

906 Lars P. Feld and Stefan Voigt, Economic Growth and Judicial Independence: Cross Country Evidence Using a New Set of Indicators, April 2003 